IBAD Sosyal Bilimler Dergisi

IBAD Journal of Social Sciences

dergipark.org.tr/ibad

IBAD, 2021; (9): 252-266

DOI: $10.21733 /$ ibad. 837065

Özgün Araştırma / Original Article

\title{
Sosyal Demokrat Refah Devletlerinde Evrensel Temel Gelir: Finlandiya Örneği
}

\section{Universal Basic Income in Social Democrate Welfare States: The Example of Finland}

\section{Ahmet Cem Esenlikci ${ }^{*}$ \\ Mehmet Ali Engin ${ }^{2}$}

\section{* Sorumlu yazar \\ Corresponding author}

${ }^{1}$ Doktora Öğrencisi, İstanbul Üniversitesi, Türkiye

$\mathrm{PhD}$. Student, Istanbul University, Turkey

cesenlikci@ktu.edu.tr

ORCID ID 0000-0002-4900-3398

${ }^{2}$ Doktora Öğrencisi, Marmara Üniversitesi, Türkiye, PhD. Student, Marmara University, Turkey

mehmetaliengin@ktu.edu.tr

ORCID ID 0000-0002-2217-7443

Makale geliș tarihi / First received : 07.12.2020

Makale kabul tarihi / Accepted : 07.01.2021

\section{Bilgilendirme / Acknowledgement:}

Yazarlar aşağıdaki billgillendirmeleri yapmaktadırlar:

1- Araştırmacıların katkı oranları eşittir.

2- Makalenin yazarları arasında çıkar çatışması bulunmamaktadır.

3- Makalemizde etik kurulu izni ve/veya yasal/özel izin alınmasını gerektiren bir durum yoktur.

4- Bu makalede araştırma ve yayın etiğine uyulmuştur.

This article was checked by Turnitin. Similarity Index 10\%

\section{Atıf bilgisi / Citation:}

Esenlikci, A.C., Engin, M.A. (2021). Sosyal demokrat refah devletlerinde evrensel temel gelir: Finlandiya örneği. IBAD Sosyal Bilimler Dergisi, (9), 252-266. 
Öz

Esping-Andersen tarafından yapılan refah devleti siniflandirmasinda Sosyal Demokrat Refah Devletleri grubunda bulunan Finlandiya, Avrupa'da evrensel temel gelir uygulamalarının öncüsü olarak görülmektedir. Finlandiya'da temel gelir uygulaması ilk kez 1971 yılında Samuli Paronen tarafından önerilmiş ve sonrasında temel gelir uygulaması ile ilgili birçok çalışma yapılmıştır. Finlandiya'da çeşitli dönemlerde yaşanan ekonomik krizler yüksek oranda ve uzun süreli işsizliğin ortaya çıkmasına sebep olmuş; işsizlik sorununun ortadan kaldırılmasında temel gelir uygulaması ön plana çıkmıştır. Juha Sipilä Hükümeti döneminde ilk kez ulusal temel gelir uygulaması tasarlanmış ve 2017-2018 yıllarını kapsayacak biçimde iki yıllık bir süre için hayata geçirilmiştir. Temel gelir uygulaması Finlandiya Sosyal Sigorta Kurumu olan Kela'dan işsizlik ücreti alan 25-58 yaş arası 2000 kişi üzerinde uygulanmıştır. Bu kişilere Kela tarafından vergilendirmeden muaf 560 avro aylık ücret ödemesi yapılmıştır. Bu çalışmada, özellikle son dönemde, COVID salgını nedeni ile gündeme gelen evrensel temel gelir konusu literatürde yer alan çalışmalar ile incelenmekte ve Finlandiya uygulaması ile değerlendirilmektedir. Yapılan değerlendirmede evrensel temel gelirin istihdam ve refah açısından oldukça etkili olmasına rağmen, maliyet açısından uygulanmasının çok mümkün olmadığı sonucuna varılmıştır.

\section{Anahtar kelimeler}

Evrensel Temel Gelir, Refah Devleti, Vatandaşlık Geliri, Finlandiya

\section{ABSTRACT}

In the welfare state classification made by EspingAndersen, Finland, which is in the group of Social Democratic Welfare States, is seen as the pioneer of universal basic income practices in Europe. In Finland, basic income practice was first proposed by Samuli Paronen in 1971, and then many studies on basic income practice were carried out. The economic crises experienced in various periods in Finland caused the emergence of high and long-term unemployment; basic income application has come to the fore in eliminating the unemployment problem. For the first time in the Juha Sipilä Government, the national basic income practice was designed and implemented for a two-year period covering 2017-2018. The basic income application was implemented on 2000 people aged 25-58, who received unemployment wages from Kela, the Finnish Social Insurance Institution. These people were paid 560 Euro monthly fee exempt from taxation by Kela. In this study, the issue of universal basic income, which has come to the fore especially recently due to the COVID pandemic, is examined with the studies in the literature and evaluated with the Finland application. In the evaluation made, it was concluded that although universal basic income is quite effective in terms of employment and welfare, it is not very possible to apply in terms of cost.

\section{Keywords}

Universal Basic Income, Welfare State, Citizenship Income, Finland 


\section{GíRIŞ}

Gün geçtikçe birçok ülkede kişiler arasındaki gelir dağılımı adaletsizliği artış göstermektedir. Yaşanan makroekonomik ve teknolojik gelişmeler sonucunda birçok kişi işgücü piyasası dışına itilerek işsiz kalmaktadır. Dönemsel olarak küresel çapta yaşanan ekonomik krizler sonucunda da pek çok ülkede işsizlik olgusu kronik hale gelmiştir. Dahası 2019 yılı sonunda Çin'de ortaya çıkan COVID19 virüsü 2020 yılı itibari ile bütün dünyayı etkisi altına almış; neredeyse bütün insanlar gelir kaybına uğramıştır. Küresel çapta yaşanan bu gelişmeler sonucunda gelir kayıplarının önlenmesi ve gelir dağılımı adaletsizliğindeki derinlemesine artışın önüne geçilmesi ihtiyacı evrensel temel gelir uygulaması düşüncelerini ön plana çıkmasını sağlamıştır. En temel tanımıyla evrensel temel gelir, kişilerin hayatlarını idame ettirebilmeleri için gerekli olan temel ihtiyaçlarını karşılayabilecek geliri ifade etmektedir ve bu gelir hiçbir koşula tabi olmaksın devlet tarafından tüm vatandaşlara verilecektir.

Esping-Andersen'in yapmış olduğu refah devletleri ayrımı doğrultusunda Sosyal Demokrat Refah Devletlerinin evrensellik, eşitlik ve sosyal haklar temel ilkeleri üzerine inşa edildiği görülmektedir. Sosyal Demokrat Refah Devletlerinin üzerine kurulu olduğu ilkeler dikkate alındığında evrensel temel gelir uygulamalarının bu devletlerde diğer devletlere göre daha etkili bir biçimde gerçekleştirileceği ifade edilmektedir. Sosyal Demokrat Refah Devletlerinin etkili örneklerinden birini oluşturan Finlandiya, Juha Sipilä Hükümeti döneminde evrensel temel gelir uygulamasını 2017-2018 yılları arasında etkin bir şekilde uygulayan ilk devlet olmuştur. Üç bölümden oluşan bu çalışmada ilk bölümde refah devletinin ortaya çıkışı ve türleri; ikinci bölümde evrensel temel gelir kavram1; son bölümünde ise Finlandiya' da evrensel temel gelirin ortaya çıkışı ve evrensel temel gelir uygulamalarının gelişimi anlatılmaktadır.

\section{REFAH DEVLETI KAVRAMININ ORTAYA ÇIKIŞI, TANIMI VE SINIFLANDIRILMASI}

Son yıllarda yeniden dünya gündemine oturan Refah Devleti, sosyal bilimciler arasında popüler bir konu olmaya devam etmektedir. Özellikle Çin'de ortaya çıan ve daha sonra bütün dünyayı etkisi altına alan Covid19 pandemisi sonrası neredeyse tüm ülkelerde yurttaşlara çeşitli isimler altında maddi ve ayni yardımlar yapılmakta, Refah Devleti kavramı tartışmaya açılmaktadır. Devletlerin ne kadar "Refah Devleti" tanımı kapsamına girdiği yapılan yardımlara göre değerlendirilmekte, bu durum da Refah Devleti türlerinin önemini ortaya çıkarmaktadır.

Refah Devleti türlerine geçmeden önce kavramın ortaya çıkışı, tanımı ve gelişimi üzerinde durmak faydalı olacaktır. Refah Devleti kavramının tarihte ilk kez nerede ve kim tarafından kullanıldığı hakkında literatürde değişik görüşler bulunmaktadır. Rosanvallon (2004, s. 119) Refah Devleti kavramının Fransızcada ilk kez II. Cumhuriyet döneminde hem genişleyen devlet yetkilerine hem de aşırı bireyciliğe karşı çıkan Liberal düşünceye sahip aydınlar tarafından kullanıldığ1 görüşünü ortaya atmaktadır. Vivekanandan ve Kurian (2005, s. 1), Refah Devleti kavramının ilk kez İsveç Sosyal Güvenlik Sisteminin mimarı olan İsveç Sosyal Demokrat Partili politikacı Gustav Möller tarafından 1928 yılında seçim bildirgesinde kullanıldığını ifade etmektedir. Özdemir'e (2007, s. 16) göre ise kavram 1941 yılında Başpiskopos Temple tarafından yazılan bir kitapta ilk kez kullanılmıştır.

Kavram ile ilgili geçmişten günümüze çok sayıda tanım yapılmıştır. Literatürde Refah Devleti konusunda en çok referans gösterilen tanım şüphesiz Asa Brigss'e aittir. Asa Brigss Refah 
Devletini piyasa güçlerinin eylemlerinin sonuçlarını siyaset ve yönetim ile değiştirmeyi amaçlayan örgütlü kamu gücünün kullanıldığ1 devlet türü olarak tanımlamıştır. Yine Brigss'e göre Refah Devleti toplumdaki bireylere ve ailelere minimum gelir garantisi sağlamalı, bireyleri ve aileleri işsizlik, yaşlılık, hastalık gibi sosyal risklerin üstesinden gelmeleri için destekleyerek söz konusu riskleri minimize etmeli ve statü ve sınıf ayrımı yapılmaksızın bütün yurttaşlara eşit sosyal hizmetler sunmalıdır. Bu üç koşul bir devletin Refah Devleti sayılması için olmazsa olmaz koşullardır (Brigs, 2000, s. 18).

Refah Devleti tanımlarının analizinde önemli konumda bulunan iki sosyal bilimci Richard Titmuss ve Harold Wilensky'dir. Titmuss'a göre Refah Devletinin varlığı yoksullara daha yüksek refah sağlamayı içermektedir. Ona göre refah devletinin sağladığı yeniden dağıtım mekanizması sosyal politikalar vasıtası ile zenginlerden yoksullara, çalışan insanlardan çalışamayan insanlara maddi ve maddi olmayan kaynakların yeniden tahsis edilmesini sağlamaktadır (Titmuss 1974' ten Aktaran Ştefan, 2015, s. 49).

Wilensky (2002, s. 211), Refah Devletini tanımlarken asgari yaşam standartlarını sosyal bir hak olarak dikkate almaktadır. Wilensky'nin bakış açısına göre sosyal haklar Refah Devleti kavramını anlamada temel nokta olarak görülmektedir. Refah Devletinde hükümet her yurttaş için asgari gelir, beslenme, sağlık, güvenlik, eğitim ve konut gibi sosyal hakları minimum seviyede sağlamakla yükümlüdür.

Özdemir (2004, s. 28), Refah Devletini genellikle sağlık, eğitim, gelirin korunması ve konut gibi temel sosyal hizmetlerin sağlanmasını amaçlayan devlet önlemleri şeklinde tanımlamaktadır. Devlet mekanizması vasıtası ile çeşitli gelir grupları arasında gelirin yeniden dağıtımı ve bu dağıtımın sağlanması için yasal mevzuatın hazırlanarak gerekli kurumların oluşturulması Refah Devletinin amacı olarak ifade edilebilmektedir.

Refah Devletlerinin sınıflandırılması ile ilgili geçmişten günümüze çok sayıda çalışma yapılmıştır. Konu ile ilgili ilk çalışma 1958 yılında Wilensky ve Lebaux tarafından yapılan ve Refah Devletlerini "kurumsal" ve "kalıntı" olarak ayıran çalışmadır. Yapılan çalışmada kalıntı refah devletlerinde refah sunma görevi aile ve piyasada iken kurumsal refah devletlerinde refahın sunulması devletin görevi olarak ifade edilmiştir (Abrahamson, 1999, s. 395). Refah devletinin sınıflandırması ile ilgili sonraki çalışma Richard Titmuss'a aittir. Titmuss çalışmasında üçlü bir sınıflandırmaya giderek refah devletlerini "kalıntı refah modeli" (devletin yoksulluğu asgari düzeye düşürdüğü model), "endüstriyel başarı-performans modeli" (istihdam durumunun refah durumunu yansittığ model) ve "kurumsal yeniden dağıtım modeli" (ihtiyaçlara bağlı olarak yurttaşlarına evrensel hizmetler sunan model) olarak sinıflandırmıştır (Pierson, 1998, s. 778).

Sosyal korumada finansmanın kimin tarafından sağlandığı refah devletleri sınıflandırması için kullanılan önemli bir ayrımdır. Bu sınıflandırmaya göre refah devletleri "Beveridge Modeli", "Bismark Modeli" ve "Karma Model" olmak üzere üçe ayrılarak incelenmektedir. Beveridge Modelinde bir ülkede yer alan bütün yurttaşları kapsayan genel bir sigorta söz konusu iken Bismark Modelinde her çalışanın sosyal refah sistemine kendisi veya işvereni tarafından yaptığı katkı kadar faydalanması durumu söz konusudur. Karma Modelde ise bahsedilen iki sistem birlikte uygulanmasından oluşmaktadır. Refah devletlerini üçe ayırarak bir sınıflandırma yapılan diğer bir çalışmada Furniss ve Tilton tarafından yapılan çalışmadır. Çalışmada refah devletleri "sosyal refah devleti", "sosyal güvenlik devleti" ve "pozitif devlet" 
olarak sınıflandırılmış, her modele sırası ile İsveç, İngiltere ve ABD örnek verilmiştir (Özdemir, 2005, s. 236-237).

Literatürde refah devletlerinin sınıflandırması ile ilgili en çok referans gösterilen çalışma Gosta Esping-Andersen tarafından 1990 yılında yapılan "The Three Worlds of Welfare Capitalism" isimli çalışmadır. Çalışmada Esping-Andersen refah devletlerini üçlü bir ayrıma tabi tutarak "Sosyal Demokrat Refah Modeli", "Liberal Refah Modeli" ve "Muhafazakâr-Kita Avrupası Refah Modeli" olmak üzere sınıflandırmıştır (Esping-Andersen, 1990, s. 26-27).

İsveç, Danimarka, Finlandiya, Norveç ve Hollanda'nın örnek ülkeler olarak gösterildiği Sosyal Demokrat Refah Modelinde evrensellik, eşitlik ve sosyal dayanışma öne çıkan ilkelerdir. Devletin temel refah sağlayıcı olduğu bu modelde, devlet yurttaşlarına çok sayıda sosyal haklar sağlamaktadır. Bu gruba giren ülkelerde yüksek istihdam ve sendikalaşma oranları mevcuttur. Almanya, Fransa, İtalya ve Belçika'nın yer aldığı Kıta Avrupası Refah Modelinde sosyal güvenlik konusu yüksek istihdamdan daha fazla ön plana çımaktadır. Aileye çok fazla önem verilen bu modelde refah hizmetlerinin sunulması konusunda aile en önemli aktördür. Yine aynı modelde devlet gelir kaybına uğrayan yurttaşlarına istihdam imkanları sağlamak yerine kaybettikleri gelir kaybını tazmin etme yolunu seçmektedir. ABD, Kanada ve Yeni Zelanda'nın örnek teşkil ettiği Liberal Refah Modelinde ise refah sağlama konusunda piyasa aktörleri önem arz etmekte ve devletin yurttaşlara sağladı̆̆ı imkanlar minimum seviyede kalmaktadır. Liberal Modelde kamu istihdamı oldukça düşüktür ve tam istihdam kamu politikalarının bir hedefi değildir (Özdemir, 2007, s. 134-141).

\section{EVRENSEL TEMEL GELİR}

Devletin ülkede bulunan tüm yurttaşlara yalnızca toplumun bir ferdi olmaları sebebi ile elde ettikleri bütün gelir ve servetlerden bağımsız olarak temel ihtiyaçlarını karşılayacak düzeyde düzenli, koşulsuz ve mütevazi bir gelir bağlanması olarak tanımlanan evrensel temel gelirin tarihi çok eskiye dayanmaktadır. Evrensel temel gelir geçmişten bugüne yapılan çalışmalarda "vatandaşlık ücreti", "devlet bonusu", bölgesel temettü" gibi çeşitli isimlerle ifade edilmiştir (Van Parijs, 2004, s. 7-8).

Tarihsel perspektiften bakıldığında evrensel temel gelir düşüncesine çok sayıda yazar ve düşünürün katkı yaptığı görülmektedir. Evrensel temel gelirin temellerinin Thomas Moore'un Ütopya isimli kitabına dayandığı söylenmektedir. Kitapta Moore, ülkede hırsızlık vakalarının yaşanmasının önüne geçilmesinin ancak insanlara temel ihtiyaçlarını karşılayacak düzeyde bir gelir bağlanması ile sağlanabileceğini savunmaktadır. Yine çağdaş Katalan düşünür Joan Lluis Vives'in çalışmalarında da konu ile ilgili bilgiler yer almaktadır. Daha önce çeşitli düşünürlerin fikirleri olsa da evrensel temel gelir ile ilgili en önemli ismin Amerikan devriminin önemli düşünürlerinden Thomas Paine olduğu görüşü ağır basmaktadır. Paine, 21 yaşına gelen her yurttaşa temel bir gelir sağlanması fikrini öne sürmüştür. Konu ile ilgili çalışmalar yaparak evrensel temel gelir düşüncesinin 19. yüzyıla taşınmasını sağlayan diğer önemli düşünürler Thomas Spence, Charles Forurier, Herbert Spencer ve Bertnard Russell örnek gösterilebilir (Raventos, 2007, s. 14-15).

20. yüzyıla gelindiğinde evrensel temel gelire ilişkin uygulama örnekleri yavaş yavaş gelişmiş ülkelerde görülmeye başlamıştır. 1969 yılında ABD başkanı Nixon evrensel temel gelir benzeri bir plan olan aile yardımı planını senatoya sunmuştur. Plana göre vatandaşlara 1600 dolar yardım yapılması hedeflenmiştir. Teklif büyük bir tartışmaya sebep olmuşsa da Temsilciler 
Meclisi'nden geçmiştir. Fakat liberallerin ve muhafazakarların oyları ile teklif ABD Senatosu tarafından reddedilmiştir (Bartlett, 2020).

ABD'nin Alaska eyaletinde vatandaşlık maaşı adı altında 1982 yılından itibaren yurttaşlara ödeme yapılmaktadır. Ödemeleri Alaska Daimi Fonu adındaki bir kuruluş organize etmektedir. Fonun geliri ise petrol gelirlerinin bir kısmından oluşmaktadır. Dönemin hükümeti tarafından petrol gelirlerinin gereksiz şekilde harcadığını düşünen halk çeşitli baskılar ile bir referanduma gidilmesini sağlamıştır. 1976 yılında yapılan referandum sonucunda petrol satışları sonucunda elde edilen gelirlerin bir kısmının Alaska Daimi Fonu'na devredilerek halka dağıtılması sonucu çıkmıştır. Söz konusu vatandaşlık maaşından yararlanmak için iki şart mevcuttur; bunlar kişinin en az 1 yıldır Alaska'da ikamet ediyor olması ve kişinin yaşıyor olmasıdır (Servante, 2017, s. 7-8).

2013 yılında bir vatandaşın evrensel temel gelir ile ilgili başarılı bir kampanya başlattığı İsviçre'de konu hükümetin her seviyesindeki paydaşların ve karar vericilerin odak noktasına oturmuş ve evrensel temel gelir konusu bütün dünya gündemine yerleşmiştir. Hükümet her İsviçre vatandaşına koşulsuz şartsız her ay 2500 İsviçre Frankı verilmesi hususu ile konuyu 5 Haziran 2016'da referanduma götürmüştür. Referandum sonucunda $\% 76,9$ oranı ile hayır oyu çıkmış ve İsviçre halkı evrensel temel gelir konusunu kapatmıştır (De Wispelaere ve Haagh, 2019, s. 237-238).

Avrupa'da evrensel temel gelir uygulaması için çalışma yapan bir diğer ülke Finlandiya'dır. 2015 yılında merkez sağ koalisyon tarafından ulusal temel gelir ile ilgili bir deneysel çalışmanın planlanıp uygulamaya geçirileceği ilan edilmiştir. Uygulanacak çalışmaya göre ülke çapında 20 ile 58 yaş aralığında yer alan 2000 işsize 2 yıl boyunca aylık 560 avro temel gelir verilmesi kararlaştırılmıştır. 2017 yılında sona eren deneysel çalışma için 2017 yılının ocak ayından bu yana analiz çalışmaları yapılmaktadır (Halmetoja vd.,2018, s. 1).

ABD ve Avrupa ülkeleri dişında da evrensel temel gelir uygulama örnekleri mevcuttur. Namibya'da 2008 yılında Otjievero ve Omitara köyleri pilot bölge seçilerek evrensel temel gelir uygulanmaya çalışılmıştır. Başkent Windhoek'in $100 \mathrm{~km}$ doğusunda olan bu köylerde yaşayan toplam 930 kişiye aylık 100 Namibya doları (Yaklaşık 8,6 avro) gelir bağlanmıştır. Hindistan'da vatandaşlık geliri ile ilgili biri UNDP diğeri UNICEF tarafından finanse edilen iki proje 2010 yılında başlatılmıştır. UNDP projesinde vatandaşlara ücretsiz yiyecek ve gaz yağı almaları ile nakit para almaları arasında tercihte bulunmaları yoluna gidilmiş ve vatandaşlar nakit parayı seçmişlerdir. UNICEF tarafından finanse edilen projede ise ülkenin en yüksek yetersiz beslenme seviyesine sahip olan Madhya Pradesh eyaletindeki 20 köy pilot bölge olarak seçilmiştir. Seçilen köylerdeki her yetişkin erkek ve kadına ayda 200 rupi (2,80 Avro), 14 yaşın altındaki her çocuk için aylık 100 Rupi verilmiştir. Bir yıl sonra yetişkinler için sağlana gelir 300 rupi ye çocuklar için sağlana gelir ise 150 Rupiye çıkarılmıştır (Perkiö, 2014, s. 5-7).

Bir ülkede bulunan bütün vatandaşlara karşılıksız olarak belirli bir gelir sağlanması konusu 2020 yılında yapılacak ABD seçimlerinde kendine yer bulmuştur. Seçimde Demokrat Parti başkan aday adayı Andrew Yang evrensel temel gelir fikrini seçim çalışmalarının temeline oturtmuş ve 18 yaşını üzerindeki her $A B D$ vatandaşına 1000 dolarlık bir gelir vadetmiştir. Andrew Yang'ın evrensel temel gelir fikri Elon Musk, Bill Gates, Mark Zuckenberg ve Jack Dorsey gibi önemli iş adamları tarafından desteklenmiştir. Fakat Yang'ın 2020 Şubat ayında yarıştan çekilmesi ile konu popülerliğini kaybetmiştir. Ayrıca COVID19 salgını neticesinde 
İngiltere başbakanı Boris Johnson'un evrensel temel gelirin salgın sırasında uygulanabilecek ihtimallerden biri olduğuna dair açılamaları ülke kamuoyunda yapılan haberlerden bilinmektedir (Uğur, 2020).

Evrensel temel gelirin tanımını yaptıktan, tarihçesinden ve bazı önemli ülke örneklerinden bahsettikten sonra konunun avantajları ve dezavantajlarına değinmek yerinde olacaktır. Literatüre bakıldığında konuya hem ekonomik hem de ideolojik yönden yaklaşan çalışmaların varlığı göze çarpmaktadır. Bu çalışmalar incelendiğinde evrensel temel gelirin avantajları ve dezavantajları şu şekilde sıralanabilmektedir (Amadeo, 2020):

Evrensel Temel Gelirin Avantajları

a. Yoksulluğun azalmasına yardımcı olur.

b. İhtiyaç sahibi yurttaşlar bürokrasi ile uğraşmadan basit bir şekilde gelire sahip olabilir.

c. Sağlanan gelirler, ekonominin resesyon dönemlerinde toplam talebi arttırarak ekonominin canlanmasına katkıda bulunur.

d. İşsizler daha iyi ve verimli çalışacakları bir iş buluncaya kadar iş aramaya devam ederler.

e. İnsanlar okula dönme ve akrabalarına bakmak için evde kalma özgürlügüne sahip olabilirler.

f. Gelir sağlanması sonucu genç çiftlerin düşük doğum oranı olan ülkelerde aile kurmaları sağlanır ve nüfus artışı sağlanır.

Evrensel Temel Gelirin Dezavantajları

a. Mal ve hizmetlere olan talep artışı nedeni ile enflasyon tetiklenebilir.

b. Ortaya çıkan enflasyon sebebi ile uzun vadede refah artışı mümkün olmaz.

c. Eğer sağlanan gelir miktarı az olursa yoksul aileler için gerçek bir fark yaratılmaz.

d. Karşılıksız sağlanan gelir insanları tembelliğe alıştırabilir.

e. İş gücüne katılım oranları düşebilir.

f. Kamu bütçesine çok fazla yük binmesine sebep olabilir.

g. Devletin artan gücü popülizme sebep olarak politikacıların keyfi davranmaları durumunu ortaya çıabilir.

\section{FİNLANDİYA'NIN TARİHİ, COĞRAFİ VE SOSYO-EKONOMIKK YAPISI}

Avrupa'nın kuzeyinde İskandinav yarımadasında bulunan Finlandiya Baltık Denizi'nin kıyısında yer almaktadır. Batısında İsveç, kuzeyinde Norveç ve doğusunda Rusya bulunan ülkenin başkenti Helsinki'dir. 2019 yılı istatistiklerine göre 5,5 milyon kişinin yaşadığı ülkede nüfusun ağırlığının ülkenin güneyinde özellikle de başkent Helsinki'de yoğunlaştığı görülmektedir. Helsinki bölgesi ülke nüfusunun yaklaşı \%27'sine (1.5 Milyon) ev sahipliği yapmaktadır. Ayrıca Finlandiya'da nüfusu 100.000'den fazla olan toplam dokuz şehir bulunmaktadır. Ülkenin yüz ölçümü 338.000 km2 olup ortalama nüfus yoğunluğu km2 başına 18 kişidir (European Commission, 2020).

1995 yılında Avrupa Birliğine üye olan Finlandiya 2002 yılından itibaren birliğin para birimi olan Euro'yu kullanmaktadır. 2019 yılı istatistiklerine göre ülkede kişi başı milli gelir 43.485 
Euro'dur. Finlilerin ortalama ömürleri yapılan çalışmalar sonucunda erkeklerde 78 yıl, kadınlarda ise 84 yıl olarak hesaplanmaktadır. Ülkenin resmi dili Fincedir ve nüfusun $\% 87,9 \mathrm{u}$ bu dili kullanmaktadır. Nüfusun \%5,2 ise İsveççe konuşmaktadır. Finlilerin inanç yapısına bakıldığında nüfusun \%70,9'unun Protestan olduğu görülmektedir. Ayrıca ülkede on binlerce Müslüman ve az sayıda da olsa Yahudi olduğu Finlandiya makamlarınca bilinmektedir (This is FINLAND, 2020)

Finlandiya'nın tarihine bakıldığında ülkenin orta çağdan 19. yüzyıla kadar 600 yıldan uzun bir süre İsveç'in bir parçası olduğu görülmektedir. Bu süre zarfında İsveç ve Rusya Finlandiya toprakları için sık sık savaşmış, nihayet 1809 yılında ülke toprakları Rusya egemenliğine girmiştir. Rusya egemenliğinde bulunduğu dönemde Finlandiya özerk bir bölge konumunda olmuş, 20. yüzyılın başında ise bu özerklik Rusya tarafından kısıtlanmıştır. Birinci Dünya Savaşı sonlarında Finlandiya Parlamentosu bağımsızlık ilan etmiş ve Rusya'nın boyunduruğundan kurtulmuştur. 1939 yılında Sovyetler Birliği'nin saldırısına uğrayan Finlandiya, 1944 yılına kadar Sovyetler Birliği ile iki savaş yapmış ve bu iki savaşta da mağlup olmuştur. 1990 yılına kadar Sovyetler Birliği hakimiyetinde olan ülke bu sürede tarım ülkesinden sanayi ülkesine dönüşmüştür. Nitekim 1990 yılında Sovyetler Birliği'nin dağılması ile Finlandiya yeniden bağımsızlığına kavuşmuştur (Repuclic of Finland Ministry of Economic Affairsand Employment ,2018, s. 53-54).

Finlandiya'nın ekonomisi incelendiğinde ekonomik göstergelerin oldukça iyi olduğu göze çarpmaktadır. 2018 yılı rakamları ile ülkenin gayrisafi yurtiçi hasılası 276 milyar dolar, enflasyon oranı \%1,2, işsizlik oranı ise \%7,4 olarak kayda geçmiştir. Başlıca ihracat malları otomobil, yarış arabaları, petrol yağları, paslanmaz çelikten yassı hadde mamulü olan Finlandiya'nın ithal ettiği ürünlerde ise ham petrol, ilaç ve kara taşıtları için parçalar öne çıkmaktadır. İhracat ve ithalat partnerleri incelendiğinde ise İsveç, Almanya ve Hollanda her iki ticarette de yer alan ülkeler olarak karşımıza çıkmaktadır (T.C. Dış İşleri Bakanlığı, 2020).

Dünya Ekonomik Forumu tarafından hazırlanan ve ülkelerin rekabet gücünün hesaplandığ1 “Küresel Rekabet Gücü İndex 4.0” isimli raporda 2019 yılı için 141 ülke içinde Finlandiya 11. sırada yer almaktadır. Yine aynı raporda Finlandiya organize suç oranlarının azlığı, polis hizmetlerine ulaşım, yargı bağımsızlığı, mülkiyet hakları, enflasyon, aktif nüfus içindeki dijital beceriler, KOBI'lerin finansmanı gibi konu başlıklarında bütün ülkeler içinde birinci sırada yer almaktadır (World Economic Forum, 2019).

\section{FINLANDIYYA'DA EVRENSEL TEMEL GELİRIN GELIŞSIMI}

Finlandiya'da temel gelir uygulaması fikrini 1971 yılında öneren ilk yazar Samuli Paronen olmuş ve daha sonraki eserlerinin birçoğunda temel gelir fikrini yinelemiştir. Paronen eserinde herkese asgari geliri garanti edecek bir "bağımsız gelir" veya "yaşam geliri" önermiş ve bu gelirden yararlanmanın tek şartını "insan olmak" olarak ifade etmiştir (Andersson, 2000: 227). Daha sonrasında temel gelir 1980 yılında Osmo Soininvaara ve Osmo Lampinen tarafından yazılan Suomi 1980-Luvulla (1980'lerde Finlandiya) adlı bir kitapta, "vatandaşlık geliri" terimi altında tanıtılmıştır (Ikkala 2012: 66). Yayınlanan bu kitabı 1980'lerde oluşturulan daha somut temel gelir önerileri izlemiştir. 1980'lerde ve 1990'larda temel gelire ilgi hızla artmış ve fikir akademisyenler, politikacılar ve bireysel aktivistler tarafından gündeme getirilmiştir. Temel gelirle ilgili modeller tasarlanmış, raporlar, makaleler yayınlanmış ve seminerler 
düzenlenmiştir. 1990'ların ortalarından itibaren ise siyasi partiler temel geliri gündemlerini koymaya başlamıştır (Perkiö, 2013, s. 4).

1986 yılında Ulusal Sosyal Refah Kurulu ilk olarak "Temel Geçim" ve daha sonra "Hanelerde Yoksulluk " ile ilgili bir rapor yayınlamıştır. Bu raporlarda, "gelir garantisi" terimi, temel gelir ile "geçim sübvansiyonu" arasında bir anlam ifade edecek şekilde kullanılmıştır. Bu geçim sübvansiyonu, Finlandiya'da başta herhangi bir geliri olamayan tüm vatandaşlar için gelir garantisi oluşturmaktadır. Temel gelir tartışmalarına Mart 1987'deki Parlamento seçimleri öncesinde siyasetçilerde katılmışlar; fakat "temel gelir" ve "vatandaşlık maaşı" gibi kavramları kullanmamışlardır. Sağ partiler "negatif gelir", sol parti (komünistler) "vatandaşlık ücreti" kavramını kullanmış, Yeşiller Partisi temel gelir kavramının temel savunucusu olarak kavramı olduğu gibi kullanmış ve Sosyal Demokratlar ise şüpheli bir yaklaşım izlemiştir (İkkala, 2012, s. 67).

1987 yılında temel gelir Mecliste yaşanan tartışmalar sonucunda yeni bir kavram olarak ortaya çıkmıştır. Yeni temel gelir kavramı, işsiz kalan bireylere ödeme yapmak yerine, sosyal güvenliğin geçici istihdamı daha cazip hale getirmek için küçük ücretlerle birleştirilebileceği fikrini taşımıştır. Bu düşünce, Yeşiller Partisi Milletvekili Osmo Soininvaara tarafından geliştirilmiş ve "temel gelir veya vatandaşlık ücreti, herkesin kazançlarının temelini oluşturmak için belirli bir miktar para alacağı anlamına gelir ve bu gelir, emek geliri ile doldurulacaktır" şeklinde ifade edilmiştir (Genel Oturum, 5 Ekim 1988). Bu yeni düşünce muhtemelen 1994'te gerçekleşen temel gelir tartışmasındaki söylemsel değişimin yolunu açmış ve temel gelirin değişen politik iklimle daha iyi yankı uyandıracak şekilde yeniden çerçevelenmesini sağlamıştır (Perkiö, 2019, s. 16).

1990'larda Finlandiya'nın yaşamış olduğu ciddi ekonomik krizin ardından temel gelir fikri, savunucuları tarafından sosyal politikada gelişen politik iklimle daha iyi yankı uyandıracak şekilde güçlü bir biçimde yeniden çerçevelenmiştir. Temel gelir, bürokratik kontrol ve yaptırımlara odaklanan geleneksel aktivasyon önlemlerinden farklı olsada, ağırlıklı olarak aktivasyon politikası için bir araç olarak anlaşılmıştır. Sosyal güvenliğe özgü teşvik tuzaklarını ortadan kaldırıp küçük bir güvenli geliri garanti ederek, temel gelirin bireylerin ekonomik faaliyetlerini arttırması beklenmektedir. 1990'ların ortasında ve sonunda hem Merkez Parti hem de Yeşiller Partisi (küçük bir liberal parti, Genç Finliler) aktivasyon perspektifinden temel geliri savunmuştur. Buna karşılık, Sol İttifak, gelir eşitsizliğini azaltmayı ve savunmasız işçiler için pazarlık gücünü arttırmayı amaçlayan ilerici bir "vatandaşlık gelirini" savunmuştur (Halmetoja vd., 2019, s. 320).

1998 yılında siyasi partiler temel gelir uygulamalarına yönelik ilk modellerini oluşturmuştur. Meclis seçim kampanyasında, Genç Finliler (o sırada mecliste iki sandalyeye sahip küçük bir liberal parti), küçükler için azaltılmış bir oranda ve emekliler için ise daha yüksek bir orana sahip, kısmi bir temel gelir için ayrıntılı bir öneride bulunmuşlardır. Merkez Parti ise (o sırada ikinci büyük parti), koşullu bir temel gelir fikrini de içerinde bulunduran "iş reformu" önerisinde bulunmuştur (Merkez Partisi, 1998a, 1998b). 1999 meclis seçimlerinde Genç Finlilerin meclisteki varlığını yitirmesi ve Merkez Partisinin muhalefette kalması sonucunda oluşturulan temel gelir önerileri hayata geçirilememiştir (Andersson, 2000, s. 233; Koistinen ve Perkiö, 2014, s. 33). 
2006'dan itibaren, birkaç yıl süren sessizlikten sonra, temel gelir tartışması sivil toplumda ve medyada hızla ortaya çıkmıştır. Yeşiller Partisi 2007 yılında parlamento seçimlerinden önce, kamu ekonomisi ve gelir dağılımı üzerindeki etkisini tahmin etmek için ilk kez mikro simülasyon (gerçek dünyadaki bir işlemin küçük boyutlu bir uygulaması) modellemesini kullanan kısmi bir temel gelir sisteminin uygulanması için bir model yayınlamıştır. Daha sonrasında Sol İttifak 2011 yılında parlamento seçimlerinden önce Yeşiller Partisinin temel gelir modelini daha geniş bir şekilde ele alan bir mikro simülasyon modeli oluşturmuştur. Her iki modelde konut yardımları, sosyal yardımlar ve kazançla ilgili faydalara dokunulmadan; referans noktası olarak asgari işsizlik, güvenliği sağlamak ve "temel geliri" gelir vergilendirmesi yoluyla finanse etmek üzerine kurulmuştur (Halmetoja vd., 2019, s. 321; Koistinen ve Perkiö, 2014, s. 33).

Son yıllarda, birçok kuruluş fayda sistemini düzene sokmak ve vergileri genellikle temel gelirin bazı unsurlarını içeren faydalarla entegre etmek için önerilerde bulunmuştur. Konu ayrıca ana akım medyada düzenli olarak yer almıştır. 2013'te tartışma, temel gelir savunuculuk grubu BİEN Finlandiya'nın bir vatandaşın inisiyatif kampanyası yürütmesiyle hızlanmış; nihayetinde gerekli miktarda imza toplamada başarısız olurken, girişim temel gelir için medyanın ilgisinin daha artmasını sağlamıştır (Halmetoja vd., 2019, s. 321). 2015 yılında iktidarda olan Başbakan Juha Sipilä Hükümetinin programında temel gelir uygulaması formüle edilen kilit projelerden birisi olarak ortaya çıkmaktadır. Temel gelir uygulamasının amacı sosyal güvenlik sisteminin daha katılımcı ve teşvik tabanlı yapılması, çalışma hayatında değişikliklere uygun olarak Fin sosyal güvenlik sistemi reformunun gerçekleştirilmesi, karmaşık fayda sisteminin basitleştirilmesi ve bürokrasinin azaltılması şeklinde ifade edilmiştir (Kela, 2015, s. 10). 1 Ocak 2017 de başlatılan temel gelir uygulaması iki yıllık süre için planlanmış ve 2018 yılının sonunda sona ermiştir.

\section{FINLANDIYA’DA EVRENSEL TEMEL GELIR UYGULMALARI}

Finlandiya'da sosyal güvenlik sisteminin sorunlarının tartışılması uzun zamandır devam etmektedir. Özellikle 1990'larda yaşanan şiddetli ekonomik durgunluktan bu yana, Finlandiya Hükümeti birbiri ardına sosyal güvenlik sisteminde reform yapılması gerektiğini kabul etmiştir. Başbakan Juha Sipilä Hükümeti (2015-2019) ayrıca, değişen bir çalışma hayatının gereksinimlerini daha iyi karşılayacak, çalışma için daha fazla teşvik sağlayacak, daha az bürokrasi içerecek ve her şeyden önce mevcut sistemden daha az karmaşık olacak şekilde sosyal güvenlik sistemini reform etmeye çalışmıştır. Hükümet ayrıca temsili demokrasinin bir parçası olarak bir deney kültürünü teşvik etmeye çalışmıştır. Fikir, küçük ölçekte sosyal yardımlar ve hizmetler sunmak için farklı yeni modeller deneyerek, bu yeni modellerin ülke çapında uygulanma şekli hakkında yararlı bilgiler elde etmeyi sağlayacaktır (Kangas vd., 2019, s. 8).

2015 sonbaharında, Başbakanlık Ofisi temel gelir uygulamasını tasarlamak için ihale açmıştır. Katılımcı araştırma gruplarının bilimsel kalitesi ve yetkinliğinin değerlendirilmesinden sonra, temel gelir uygulamasının planlanması Finlandiya Sosyal Sigorta Kurumu'nun (Kela) Araştırma Departmanı tarafından yönetilen bir konsorsiyuma bırakılmıştır (Kangas vd., 2017, s. 87). Konsorsiyumun görevi kendisine çizilen çerçeve dahilinde, temel gelir uygulaması için farklı temel gelir modellerinin uygunluğunu incelemek olarak belirtilmiştir. Başbakanlık Ofisi tarafından verilen görev sonucunda konsorsiyum tarafından temel gelir uygulaması için dört farklı seçenek sunulmuştur (De Wispelaere vd., 20018, s. 6); 
a. Tam Temel Gelir: Tam temel gelir, mevcut olan diğer sosyal sigorta temelli faydaların büyük bir kısminin yerini alacak bir model olarak ifade edilmektedir. Tam temel gelir uygulamasında, temel gelir seviyesinin mevcut temel sosyal güvenlikten daha yüksek olacağı anlamına gelmektedir. Finlandiya'da, özellikle yüksek temel gelirin otomasyonun neden olduğu teknolojik işsizliğe bir cevap olarak görüldüğü 1980'lerde bu tür modeller önerilmiştir. Tam temel gelir uygulaması Finlandiya'da, emek arzını azaltmaya yardımcı olacak ve bu şekilde iş ve servetin daha eşit dağılımına izin verecek ve insanlara ücretli iş dışında katılımcı fırsatlar sağlayacak bir araç olarak görülmüştür (Kela, 2016, s. 24).

b. Kısmi Temel Gelir: Finlandiya'da temel gelir uygulamaları konusundaki tartışmalarda temel gelir genellikle kısmi temel gelir olarak adlandırılmıştır. Bu anlamda temel gelir, sosyal sigorta temelli faydaların bir kısmının yerini aldığı ve temel gelir uygulamasının diğer sosyal güvenlik uygulamaları ile birlikte uygulandığı bir model olarak ifade edilmektedir. Finlandiya'daki en gelişmiş kısmi temel gelir modelleri Yeşiller Partisi (2007/2014) ve Sol İttifak (2011) tarafından öne sürülmüştür. Sosyal yardım, konut ödeneği ve kazanç ile ilgili faydalar her iki modelde de korunacaktır. Bu modeller üzerinde kayıt temelli mikro simülasyonlar yapılmış ve bunlardan kaynaklanan maliyet, teşvik ve gelir dağılımı etkilerinin değerlendirilmesine olanak sağlamıştır. Kısmi temel gelir modellerinde yaygın olarak vergilendirme yoluyla, orta gelirli ve yüksek gelirli kişilerin temel gelir yoluyla kazandığı ekonomik avantajları ortadan kaldıracaktır. Gelir dağılımı etkileri, temel gelirin seviyesine ve gelir vergisinde uygulanan ilerlemeye bağlı olarak değişim gösterecektir (Kela, 2015, s. 53).

c. Negatif Gelir Vergisi: İlk olarak 1960'larda Amerikalı ekonomistler tarafından önerilen negatif gelir vergisi, bir bireyin geliri kararlaştırılan asgari seviyenin altında kaldığında vergilendirme yoluyla gelir tazminatına dayanan bir sosyal güvenlik ve vergi planıdır. Tanımı açısından, negatif gelir vergisi temel gelirle aynı değildir, ancak benzer sonuçlara sahip olabilmektedirler. Her iki model de asgari geliri garanti etmeyi ve iş için daha fazla teşvik sağlamayı amaçlamaktadır. Bu nedenle, kısmi temel gelir ile yapılan bir uygulama, negatif gelir vergisinin teşvik edici etkileri hakkında da bilgi sağlayacaktır. Negatif gelir vergisinin insanları modelden yararlananlar ve onu finanse edenler şeklinde daha açık bir biçimde böleceği gerçeği, kısmi temel gelirle arasındaki en önemli fark olarak görülmüştür (Kela, 2016, s. 37).

d. Diğer Temel Gelir Modelleri: Başbakanlık Ofisi temel gelir uygulaması için başka alternatiflerin incelenmesi görevini de oluşturulan çalışma grubuna vermiştir. Temel gelir uygulaması için oluşturulan diğer modeller; katılım geliri/katılımcı sosyal güvenlik, evrensel kredi/aktif refah, seçenekler-temel hesap, konut ödeneği gibi alternatiflerden oluşmuştur (Kela, 2015, s. 76).

Başbakanlık Ofisi tarafından verilen görev sonucunda konsorsiyum tarafından temel gelir uygulaması için ayrıntılı bir biçimde oluşturulan dört farklı seçenek, 30 Mart 2016'da konsorsiyumun hükümete teslim ettiği ilk raporda kapsamlı bir şekilde tartışılmıştır. Bu rapora dayanarak hükümet ilk temel gelir uygulamasının kısmi temel gelir modellerine odaklanmasına karar vermiştir (Kangas vd., 2017, s. 88).

Temel gelir uygulamasının temel amacı, çalışma hayatındaki değişikliklere daha iyi cevap verebilmek, istihdama ve sosyal güvenlik sistemine daha etkin katılımı sağlamak, bürokrasiyi azaltmak ve kamu maliyesi ile ilgili sürdürülebilir bir şekilde karmaşık faydaları sistemini 
basitleştirmek için etkili bir sosyal güvenlik reformunu gerçekleştirmek olarak belirtilmiştir (Kela, 2016, s. 58). Temel gelir uygulaması iki yıllık periyot için belirlenmiş olup, 1 Ocak 2017'den 31 Aralık 2018 kadar uygulanmasına karar verilmiştir. Temel gelir uygulamasının yönetimi Finlandiya Sosyal Sigortalar Kurumu'na (Kela) bırakılmıştır. Temel gelir uygulaması için Kela'dan işsizlik ücreti alan yaklaşık 175.000 kişin oluşturduğu hedef grup arasından katılımın zorunlu olduğu bu uygulama için rastgele 25 ile 58 yaş arsı 2000 kişi seçilmiştir. Seçilen 2000 kişiye Kela tarafından koşulsuz ve vergiye tabi olmayan 560 avro aylık olarak temel gelir ödemesi yapılmıştır. Yapılan temel gelir ödemesi kişiler bir işe girseler bile kesilmeden devam etmiştir. Bununla birlikte yapılan temel gelir ödemesi işsizler için tahsis edilen sosyal yardımlardan düşülmüş ve bunun sonucunda işsizlerin gelir seviyesinde bir değişiklik oluşmamıştır. Vergi sisteminde herhangi bir değişiklik yoktur ve temel gelir istihdam gelirinden etkilenmemiştir. Böylece, temel gelir modeli önemli ölçüde istihdam edilenlerin harcanabilir gelirini arttırmıştır. Ancak, tüm nüfus için uygulanırsa pahalı bir model olacağ1 ifade edilmiştir (Hämäläinen vd., 2019, s. 1-3; Kangas vd., 2017, s. 88).

Finlandiya Sosyal Sigortalar Kurumu olan Kela, 2017-2018 yıllarında ülkede uygulanan evrensel temel gelir ile ilgili yapılan değerlendirmelerin sona erdiğini 2020 yılının mayıs ayında ilan etmiştir. Referans süresi olan 2 yıl boyunca temel gelir alan 2000 kişiye bir anket uygulanmıştır. Anket sonuçlarına göre evrensel temel gelirin istihdama kısmi de olsa olumlu şekilde yansıdığı ifade edilmiştir. Sonuçlara göre temel gelir alan 2000 kişinin söz konusu dönemde istihdam edilme sürelerinin diğer işsizlere göre 6 gün arttığı saptanmıştır. Ayrıca temel gelir alan insanların kendilerini zihinsel anlamda ve ekonomik refah anlamında diğer işsizlere göre daha iyi hissettikleri değerlendirme sonucu ortaya çıkmıştır (Kela, 2020).

\section{SONUÇ ve ÖNERILLER}

Tarihi oldukça eskiye dayanan evrensel temel gelir düşüncesi, 19. yüzyılın ikinci yarısından itibaren çeşitli projelerle birtakım ülkelerde hayata geçirilmiştir. Bu projelerin bazıları geçici bir süre denenmiş, bazıları ise uzun yıllar sürdürülmeye devam edilmiştir. Son dönemde farklı dünya görüşlerine sahip, siyasetin her iki tarafında da yer alan partiler tarafından öne sürülüp tartışılmaya başlanmış olsa da evrensel temel gelir düşüncesinin genellikle sosyal demokrat düşünceye sahip ya da sol tandanslı partiler tarafından benimsendiği göze çarpmaktadır. Bu durum, evrensel temel gelir konusunda bütün dünyada dikkatlerin sosyal demokrat refah devletlerine çevrilmesine sebep olmuştur. Esping-Andersen tarafından yapılan refah devleti siniflandırmasinda sosyal demokrat refah devletleri grubunda yer alan Finlandiya, evrensel temel gelir düşüncesinin uygulamaya konulması açısından önemli bir örnektir. Ülkede vatandaşlara temel ihtiyaçlarını karşılamaya yetecek seviyede ve hiçbir koşul aranmaksızın bir gelir bağlanması konusu çeşitli tarihlerde çok sayıda tartışmaya konu olmuştur. Nitekim bu tartışmalar 2017 yılında bir uygulama ile neticelendirilmiştir. 2018 yılında sona eren uygulama sonucunda yapılan değerlendirmeler evrensel temel gelir çalışmasının istihdam ve refah açısından kısmi de olsa olumlu etkiler bıraktığını, ancak evrensel temel gelirin bütün topluma uygulanmasının maliyet açısından pek mümkün görünmediğini ortaya çıkarmıştır.

Günümüzde ortaya çıkan COVID19 virüs salgını evrensel temel gelir düşüncesini Avrupa'nın önemli ülkelerinde ve Amerika Birleşik Devletleri'nde yeniden gündeme getirmiştir. Konu kamuoyunda tartışılmakla birlikte ülkelerde bir uygulama ortaya konulamamıştır. Savunanalar tarafından yoksulluğun ortadan kaldırılmasında, gelir adaletinin sağlanmasında ve herkesin insan onuruna yakışır bir hayat seviyesine kavuşmasında önemli bir politika 
olarak gördüğü; karşıt görüşte olanların ise gerek maliyetli olduğu gerekse insanları işsizliğe ve tembelliğe sevk ettiğini düşündüğü evrensel temel gelirin önümüzdeki yıllarda da dönem dönem gündeme geleceği gerçeğini ortaya koymaktadır.

İncelenen çalışmalarda gelişmiş ülkelerde devlet tarafından yapılacak ödemelere dikkat çekilirken bazı az gelişmiş ülkelerde çeşitli uluslararası kuruluşların tam anlamı ile evrensel temel gelir olmasa da ona benzer çalışmalar yürüttükleri görülmektedir. Bu çalışmaların şüphesiz özelde uygulandıkları ülkelerde; genelde ise dünyada yoksulluğun azalması açısından önem taşıdığı açıktır. Ancak temel anlamda yiyecek ve temiz suya ulaşmada bile sıkıntı çeken az gelişmiş ülkeler için evrensel temel gelirin devlet tarafından karşılanması ekonomik anlamda mümkün görünmemektedir. Gelişmiş ülkelerde ise durum farklılık göstermektedir. Gelişmiş ülkelerde, uygulanacak bir evrensel temel gelirin yurttaşları tembelliğe ve çalışmamaya özendireceği yönünde bir algı bulunmaktadır. Konu ile ilgili gerçek sonuçlar, söz konusu fikrin geniş tabanlı bir toplulukta uzun vadeli uygulanması ile ortaya çıkacaktır.

Hangi ülkede yaşarsa yaşasın, bir insanın sırf vatandaşlık hakkı nedeni ile hiçbir işte çalışmadan, üretmeden belirli bir miktar gelir etmesi eşitlik ve emek perspektifinden bakıldığında doğru görülmemektedir. Fakat yoksulluk gibi bir gerçekte bütün varlığı ile karşımızda durmaktadır. Bu nedenle evrensel temel gelir yerine az gelişmiş ülkelere istihdam yaratacak yatırımların yapılması daha gerçekçi olacaktır. Bunun yanında bu ülkelerde sosyal yardım ve sosyal hizmet mekanizmalarının geliştirilmesi de yoksulluğun azalmasına yardımcı olacaktır. Gelişmiş ülkelerde ise yoksulluk sınırı altında yaşayanlara, çalışan yoksullara ve alt gelir gruplarına yönelik kira yardımı, elektrik, su ve doğalgaz faturalarının belirli kısımlarına kadar muafiyet, asgari ücretin vergi dışı tutulması gibi konularda uygulanmak üzere çeşitli politikalar geliştirilebilir. Bu politikalar, evrensel temel geliri ikame edebildiği ve başarılı olduğu sürece yoksullukla mücadelede aktif olarak kullanılabilmektedir.

\section{KAYNAKÇA}

Abrahamson, P. (1999). The welfare modelling business. Social Policy \& Administration, 3(4), 394-415.

Amadeo, K. (2020). Universal basic income, its prosand cons with examples. 13 May1s 2020 tarihinde https://www.thebalance.com/universal-basic-income-4160668 adresinden erişildi.

Andersson, J. (2000). The history of an idea. Why did basic income thrill the Finns, but not the Swedes? İn Van Der Veen, Robert and Groot, Loek (Eds). In Basic income on the agenda: policy objectives and political chances. Amsterdam: Amsterdam University Press; London: Eurospan, 224-237.

Barlet, B. (2013). Rethinking the idea of a basic income for all. 13 May1s 2020 tarihinde https://economix.blogs.nytimes.com/2013/12/10/rethinking-the-idea-of-a-basicincome-for-all/ adresinden erişildi. 
Brigss, A. (2000). The welfare states in historical persperctive. C. Pierson ve F. G. Castles (Ed.). In The welfare state: a reader. Cambridge: Cambridge Polity Press. 16-29.

De Wispealere, J., Haagh, L. (2019). Introduction basic income in European welfare states: opportunitiesand constraints. Social Policy E Society, 18(2), 237-242.

De Wispelaere, J., Halmetoja, A. ve Pulkka, V. (2018). The Finnish basic income experiment: a primer. Torry, Malcolm (Eds). In The Palgrave International Handbook of Basic Income. UK: Palgrave Macmillan, Cham.

Esping-Andersen, G. (1990). The three worlds of welfare capitalism. New Jersey: Princton Universty Press.

European Commission. (2020). Finland population: demographic situation, languages and religions. 13 Mays 2020 tarihinde https://eacea.ec.europa.eu/nationalpolicies/eurydice/finland/population-demographic-situation-languages-andreligions_en adresinden erişildi.

Halmetoja, A., De Wispelaere, J. ve Perkiö, J. (2018). A policy cometin moominland? Basic income in the Finnish welfare state. Social Policy \& Society, 18(2), 319-330.

Hämäläinen, K., Kanninen, O. ve Verho, J. (2019). Evaluation of the Finnish basic income experiment: first year results. 14 Mayss 2020 tarihinde https://www.academia.edu/39840243/The_Finnish_Basic_Income_Experiment_A_Pri mer adresinden erişildi.

Ikkala, M. (2012). Finland: institutional resistance of the welfare state against a basic income. Caputo, Richard K. (Eds). In Basic income guarantee and politics: international expeririances and perspective on the viability of income guarantee. New York: Palgrave Macmillan, 61-81.

Kangas, O., etc. (2019). The basic income experiment 2017-2018 in Finland: preliminary results. Reports and Memorandums of the Ministry of Social Affairs and Health, 9, Finland: Ministry of Social Affairs and Health.

Kangas, O., Simanainen, M. ve Honkanen, P. (2017). Basic income in the Finnish context. Intereconomics, 52(2), 87-91.

Kela (2015). From idea to experiment report on universal basic income experiment in Finland. Helsinki: Authors and Research at Kela, Working papers.

Kela (2020). Results of Finland's basic income experiment. 26 Mayı 2020 tarihinde https://www.kela.fi/web/en/news-archive/

/asset_publisher/IN08GY2nIrZo/content/results-of-the-basic-income-experimentsmall-employment-effects-better-perceived-economic-security-and-mental-wellbeing adresinden erişildi.

Koistinen, P. ve Perkiö, J. (2013). Good and bad times of social innovations: the case of universal basic income in Finland. Basic Income Studies, 9(1-2), 25-57.

Özdemir, S. (2005). Sosyal gelişim düzeyleri farklı refah devletlerinin sınıflandırılması üzerine bir inceleme. Sosyal Siyaset Konferansları Dergisi, (49), 232-266. 
Özdemir, S. (2007). Küreselleşme sürecinde refah devleti. Genişletilmiş 2. Bask1. İstanbul: İstanbul Ticaret Odası Yayınları.

Özdemir, S. (2007). Küreselleşme sürecinde refah devleti. İstanbul: İstanbul Ticaret Odası Yayınları.

Perkiö, J. (2013). Basic income proposals in Finland, Germany and Spain. Vienna, Austria: Transform european network for alternative thinking and political dialogue discussion paper No. 2.

Perkiö, J. (2014). Universal basic income a new tool for development policy? International Solidarty Work.

Perkiö, J. (2019). From rights to activation: the evolution of the idea of basic income in the Finnish political debate 1980-2016. Journal Social Policy, 1-22.

Pierson, C. (1998). Contemporary challenges to welfare state development. Political Studies, XVLI, 777-794.

Raventos, D. (2007). Basic income the material conditions of freedom. London: Pluto Press.

Republic of Finland Ministry of Economic Affairs and Employment (2018). Welcome to Finland.

Rosanvallon, P. (2004). Refah devletinin krizi. (çev. Burcu Şahinli). Ankara: Dost Kitabevi.

Servante, D. (2017). AB ve dünyadaki temel gelir tartışmaları. İstanbul: İktisadi Kalkınma Vakfı.

Ştefan, G. (2015). European welfare state in a historical perpective: a critical review. European Journal of Interdisciplinary Studies, 7(1), 25-38.

T.C. Dış İşleri Bakanlığı (2018). Finlandiya'nın ekonomisi. 14 Mayıs 2020 tarihinde http://www.mfa.gov.tr/finlandiya-ekonomisi.tr.mfa adresinden erişildi.

This is FINLAND (2020). Finland in facts. 14 Mayis 2020 tarihinde https://finland.fi/facts-statsand-info/finland-in-facts-2/ adresinden erişildi.

Uğur, T. (2020). Evrensel temel gelir (ubi) ajandası: bilmeniz gereken her şey! 13 Mayıs 2020 tarihinde https://medium.com/t\%C3\%BCrkiye/evrensel-temel-gelir-ubiajandas $\% C 4 \% B 1-b i l m e n i z-g e r e k e n-h e r-\% C 5 \% 9 F e y-3 e 1 f 60 f d 8648$ adresinden erişildi.

Van Parijs, P. (2004). Basic income: a simple and powerful idea fort the twenty-firs century. Politics \& Society, 32(1), 7-39.

Vivekanandan, B., Kurian, N. (2005). Introduction: welfare states and the future. B. Vivekanandan, ve N. Kurian (Ed.). In Welfare states and the future. New York: Palgra ve Macmillan. 1-13.

Wilensky, H. (2002). The welfare state convergence and divergence, rich democracies political economy. In Public economy and performance. CA: University of California Press. 211251.

World Economic Forum (2019). The global competitiveness report 2019. 